\title{
Assessment of Functional Activity of the Bovine Thyroid Gland Using Morphometry and Two Markers of Cellular Proliferation
}

\author{
F. JELÍNEK ${ }^{1,2}$, I. KRABAČOVÁ ${ }^{1}$, V. KROUPOVÁ ${ }^{1}$ \\ ${ }^{1}$ Department of Anatomy and Physiology of Farm Animals, Faculty of Agriculture, \\ Universtity of South Bohemia, České Budějovice, Czech Republic. \\ ${ }^{2}$ Veterinary Histopathological Laboratory, Prague \\ Received March 11, 2002 \\ Accepted November 18, 2002
}

Abstract

Jelínek F., I.Krabačová, V. Kroupová: Assessment of Functional Activity of the Bovine Thyroid Gland Using Morphometry and Two Markers of Cellular Proliferation. Acta Vet. Brno 2003, 72:11-16.

The aim of the study was to contribute to objectivity of morphological investigation of thyroid gland in cattle.Thyroid gland in euthyreoid cows is composed of conspicuously different size follicles. Using image analysis the follicles were classified in accordance to their diameter in three size categories: large $(175.1-615 \mu \mathrm{m})$, medium, $(80.1-175 \mu \mathrm{m})$ and small $(15-80 \mu \mathrm{m})$. Moreover, there were considerable individually different proportions among the determined size categories of the follicles. Height of the follicular epithelium was in reverse relation to size of the follicles. Mean values were $7.06 \mu \mathrm{m}, 8.04 \mu \mathrm{m}$ and $8.39 \mu \mathrm{m}$, respectively. Proliferative activity of follicular epithelium, evaluated by means of proliferating nuclear antigen and nucleolar organizer regions was high in the small, moderate in the medium and low in the large follicles. We found these markers suitable for evaluation of proliferative activity of follicular cells in the bovine thyroid gland.

Thyroid gland, functional activity, morphometry, proliferation

Histological assessment of functional activity of the thyroid gland consists of estimation of size of the follicles, height of the follicular epithelium, quantity and colour of the colloid and proliferative activity of the epithelial cells. It is generally accepted that increased function of the thyreoidea manifest itself by smaller follicles, higher follicular epithelium, decreased quantity and eosinofilia of the colloid and by increased proliferative activity. Morphometry facilitates objective evaluation of morphological parameters of organs and tissues. It may be performed by micrometrical equipment installed in microscope or by means of computer technique with software for picture analysis. Results of morphometry of the thyroid gland using micrometer were published by Kóňová et al. (1998, 1999). Results obtained by image analysis were presented by Kratochvíl (1998).

Proliferative activity of cells can be estimated, in addition to counting the mitotic figures, by immunohistochemical detection of binding of bromodeoxyuridine (BrDU) in the nuclei, by immunohistochemical demonstration of proliferating cell nuclear antigen (PCNA) and antigen $\mathrm{Ki67}$, and also by impregantion of nucleolar organizing regions with argent nitrate (AgNOR) (Lukáš et al. 1997). Proliferative activity of the thyroid gland using BrDU was examined by Schorsch and Pohlmayer-Esch et al. (2001), by means of PCNA by Velický et al. (1997) and Di Fulvio et al. (2000) and with AgNOR by Serakides et al. (1999).

The aim of the present study was to contribute to morphological estimation of functional activity of the bovine thyroid gland. Therefore we examined the thyroids, in adition to common histological methods, also by means of image analysis to evaluate some morphometrical parameters, and by detection of PCNA and AgNOR to evaluate proliferative activity of the follicular cells. 


\section{Materials and Methods}

Thyroid glands

The study was perfomed in thyroid glands from cows slaughtered at abattoir in České Budějovice. The animals originated from ten farms located in south Bohemia and they were culled for breeding problems. The herds were saturated with iodine in mineral mixtures added to farm food in calculated quantity.

\section{Histology}

Twenty four thyroid glands were examined histologically. Immediatelly after the meat inspection the glands were collected. By means of two parallel transversal sections, in the middle of length of the lobes, samples 4-5 mm thick were fixed in $10 \%$ buffered formalin. The samples were processed by common paraffin technique. To obtain standard results of morphometrical examination, the histological sections, $5 \mu \mathrm{m}$ of thickeness, were extended on the slides using histological hot plate with digital regulation and continual monitoring of temperature. The sections were stained with hematoxylin and eosin (HE) and, in some cases, after van Gieson.

\section{Morphometry}

Morphometry was performed on histological slides from 24 thyroid glands stained with HE or after van Gieson. We used software system for processing and analyzing of colour and black and white picture LUCIA TM (Laboratory Imaging Ltd.) with colour differentiation "True Colour" 3 x 8 bits, TV camera JVC TK $-1085 \mathrm{E}$ with differentiation 752 x 524 pixels combined with microscope Alphaphot - 2YS2 Nikon. The size of the follicle was determined by measuring its two longest perpendicularly situated lengths. On the basis of examination of 30 follicles similar in size, they were classified in three categories - large, medium and small, with determined span for each category.

Heigth of the follicular epithelium was calculated as a mean of individual values of 30 cells measured in the follicles of the same size category.

\section{Gravimetry}

Estimation of proportion of the size categories of follicles in the histological sections was performed using gravimetric method. For this purpose 12 histological slides stained with HE or after van Gieson were photographed through a stereomicroscope Leica MS5 at the same magnifications. Photos were copied a constant enlarger to paper. Areas of each category of the follicles were cut out and weighed by means of analytical scales (Sartorius AC 211 P) in milligrams. Relations among the values of size categories are given in per cent (Table 2).

Immunohistochemistry

Immunohistochemical reaction for PCNA was performed on eight, randomly selected, samples of the thyroid glands. Histological sections from paraffin material were attached to slides treated with 3Aminopropyltriethoxysilane (Fluka).After the common deparaffinization, activity of endogeneous peroxidase was quenched by means of $3 \%$ peroxide for $10 \mathrm{~min}$. Nonspecific binding sites were blocked with $1 \%$ bovine albumin (Sigma) for $5 \mathrm{~min}$. For detection of PCNA clone PC 10 (DAKO) was used. Sections were incubated in wet chamber, at room temperature for $60 \mathrm{~min}$. Binding of the antibody was visualized by means of Streptavidin-Biotin Universal Detection system (IMMUNOTECH). The sections were counterstained with hematoxylin, dehydrated and mounted to Canada balsam. Positivity appeared as diffuse brown color in the nuclei. Proliferative activity was calculated in per cent of positive nuclei from total number of nuclei in 30 follicles of the same size category.

Impregnation of AgNOR

The same thyroid glands which were used for detection of PCNA were examined on AgNOR. Histological sections were impreganted after Hikino et al. (1995), as follows: Fresh solution of 50\% argent nitrate was mixed in ratio 2:1 with $1 \%$ formic acid in $1 \%$ aqueous gelatine. The impregnation was conducted for $30 \mathrm{~min}$. at room temperature. The slides were differentiated in $0.1 \%$ gold chloride for $10-15 \mathrm{sec}$. After washing and dehyration the slides were mounted to Canada balsam. Positivity was in form of brown globules of different diameter, located in the nuclei. AgNOR activity was expressed in mean number of intranuclear brown globules per 100 nuclei in the follicles of the same size category.

Statistical evaluation

Tuckey's HSD test (test of groups homogenity), analysis of variance (non-parametrical methods) from STATISTICA program package (Matoušková et al. 1992) were used for statistical evaluation of results. Graphical treatment was realised with the help of Excel 97 (Microsoft, 1997) and STATISTICA 6.0 program package (StatSoft, Inc. Tulsa, USA).

\section{Results}

Histology

Histological examination revealed in each of the 24 thyroid glands all three size categories of follicles. However, their proportion deffered among individual animals. In some glands also solid foci of the follicular cells were present. (Plate V, Fig. 1). 
Small follicles were located mainly at periphery of the lobes. They were lined predominantly with cuboidal or tall cuboidal epithelium and occasionally also columnar epithelium was seen. In several glands the follicular cells had light cytoplasm with small vacuoles. Colloid was homogeneous, eosinophilic, less frequently light, with resorption vacuoles at periphery. Follicles of medium size and large follicles were lined with cuboidal or low cuboidal epithelium with eosinophilic cytoplasm. Some cells with light cytoplasm were observed. Colloid was homogeneous, eosinophilic. Only in some follicles the resorption vacuoles were found.

In five samples, there was a higher amount of interfollicular connective tissue localized predominantly in areas of small follicles without any other pathological lesions. (Plate V, Fig. 2). We found no signs of non-purulent thyreoiditis of autoimmune nature.

\section{Morphometry}

Results of morphometry are presented in Table 1. On the basis of results of this examination the thyroid follicles were classified in three following categories:

Table 1

Morphometric parameters of bovine thyroid gland

\begin{tabular}{|c|c|c|c|c|c|c|c|c|c|}
\hline \multirow{2}{*}{ Parameter } & \multicolumn{3}{|c|}{ Large follicles $(\mu \mathrm{m})$} & \multicolumn{3}{c|}{ Medium follicles $(\mu \mathrm{m})$} & \multicolumn{3}{c|}{ Small follicles $(\mu \mathrm{m})$} \\
\cline { 2 - 10 } & Length & Width & $\begin{array}{c}\text { Height of } \\
\text { epithelium }\end{array}$ & Length & Width & $\begin{array}{c}\text { Height of } \\
\text { epithelium }\end{array}$ & Length & Width & $\begin{array}{c}\text { Height of } \\
\text { epithelium }\end{array}$ \\
\hline$\varnothing$ & $279.9 \mathrm{a}$ & $178.7 \mathrm{a}$ & $7.06 \mathrm{a}$ & $125.6 \mathrm{~b}$ & $82.3 \mathrm{~b}$ & $8.04 \mathrm{~b}$ & $49.7 \mathrm{c}$ & $34.8 \mathrm{c}$ & $8.39 \mathrm{c}$ \\
\hline $\mathrm{s}_{\mathrm{x}}$ & 84.8 & 64.2 & 2.06 & 25.2 & 21.4 & 2.31 & 13.18 & 9.39 & 2.22 \\
\hline
\end{tabular}

Significant level: length of follicles $(P<0.01)$ a:b; a:c; b:c; width of follicles $(P<0.01)$ a:b; a:c; b:c height of epithelium $(P<0.01)$ a:b; a:c; b:c

$\mathrm{n}-$ thyroid gland $=24$

Small follicles: $15.0-80 \mu \mathrm{m}$

Middle follicles: $80.1-175.0 \mu \mathrm{m}$

Large follicles: $175.1-615.0 \mu \mathrm{m}$

Large follicles of average length $297.88 \pm 50.49 \mu \mathrm{m}$. with the maximal and minimal length $614.68 \mu \mathrm{m}$ and $176.01 \mu \mathrm{m}$, respectively. Medium follicles of average length 125.84 $\pm 13.73 \mu \mathrm{m}$ with maximal and minimal length $174.59 \mu \mathrm{m}$ and $81.97 \mu \mathrm{m}$. Small follicles of average length $49.71 \pm 7.72$ with variation span from 79.87 to $17.05 \mathrm{um}$

Height of the follicular epithelium was in reverse relation to size of the follicles and results are also presented in Table 1 . The highest epithelium $(8.39 \mu \mathrm{m} \pm 2.22)$ was in the small follicles. In the medium follicles the heigth of the epithelium was $8.04 \mu \mathrm{m} \pm 2.31$ and lowest epithelium $(7.06 \mu \mathrm{m} \pm 2.06)$ was in the large follicles. Height of the epithelium in the small follicles was significantly different $(P<0.01)$ from that of medium and large follicles.

Table 2

Per cent ratio of sizes of follicles of bovine thyroid gland

\begin{tabular}{|c|c|c|c|}
\hline \multirow{3}{*}{ Parameter } & & Follicles & Small \\
\cline { 2 - 4 } & Large & Medium & $\%$ \\
\cline { 2 - 4 } & $\%$ & $\%$ & 30.4 \\
\hline$\overline{\mathrm{x}}$ & 27.8 & 41.8 & 23.7 \\
\hline \multirow{2}{*}{$\mathrm{S}_{\mathrm{X}}$} & 23.5 & 20.2 & $4.6-82.4$ \\
\hline Var. Span & $0-72.3$ & $10.3-80.0$ & \\
\hline
\end{tabular}

$\mathrm{n}$ - thyroid gland $=12$ 


\section{Gravimetry}

Results of gravimetric examination of 12 thyroid glands are presented in Table 2. Marked individual variation span of all three size catgories of the follicles was found.

\section{Evaluation of the proliferative activity}

Results of this examination are summarized in Table 3 and documented in Figs 3 and 4 (Plate VI). Highest proliferative activity was observed in the small follicles and it was proved by means of the both markers. We found statistically significant coincidence with high positive correlation between expression of PCNA and AgNOR. There were also statistically significant differences $(P<0.01)$ among the three size categories of the follicles.

Table 3

Markers of proliferative activity of bovine thyroid gland

\begin{tabular}{|c|c|c|c|c|c|}
\hline \multicolumn{3}{|c|}{ Follicles } & \multicolumn{3}{|c|}{ Follicles } \\
\hline Large & Medium & Small & Large & Medium & Small \\
\hline \multicolumn{3}{|c|}{ PCNA* } & \multicolumn{3}{|c|}{$\mathrm{AgNOR}^{* *} *$} \\
\hline 18.8 & 29.9 & 50.3 & 1.5 & 1.9 & 2.2 \\
\hline
\end{tabular}

* $(\%)$ positive cells in 30 large follicles, 30 medium follicles, 30 small follicles; $\mathrm{n}$ - thyroid gland $=8$ ** mean AgNOR/ 100 cells; $\mathrm{n}$ - thyroid gland $=8$

\section{Discussion}

In accordance with literature (Jubb et al. 1993; McGavin et al. 2001; Copenhauer 1964; Fitzgerald 1983) the histological picture of the examined thyroid glands is characteristic for high functional activity. Cotran et al. (1994) state that "thyroid gland is in a constant process of adaptation. The functional lability is reflected in transient hyperplasia of the thyroidal epithelium. At this time, thyreoglobulin is resorbed, follicular cells become tall and columnar. When the stress abates, involution occurs, the height of the epithelium falls, colloid accumulates and the follicular cells resume their normal size and architecture. Failure of this normal balance between hyperplasia and involution may produce deviations from the usual histologic pattern".

The size of the follicles is variable among different animal species, among individual animals, and in individual gland.(Novotný et al. 1966; Banks 1992). Diameter of the follicles in cattle is between 30-60 $\mu \mathrm{m}$ (Novotný et al. 1966). McGavin et al. (2001) consider 20-250 $\mu \mathrm{m}$ as normal values in animals. However, in our collection of thyroid glands the span was even more pronounced. Moreover, we found also marked individual variability of proportions of size categories of the follicles. Cotran et al. (1994) and McGavin et al. (2001) characterized diffuse nontoxic goiter as nonuniform accumulation of the colloid throughout the gland, hugely distended some follicles lined with flattened epithelium whereas others remain small and may even retain small papillary infoldings of hyperplasic cells. On the basis of this description we could suppose an insufficient supplementation of the examined cows with iodine or goitrogenic influence of some plants. On the other hand, the thyroid lobes were not enlarged and no clinical symptoms of the hypofunction of thyroids were observed.

Goitrogenic effect of thiouracil on the thyroid gland in buffalo calves was studied by Sharma (1978). The author found enlarged thyroid lobes, significant increase in height of the epithelium and reduction of the follicles size and coloid content. Similar changes were observed in lambs experimentally treated with chlorine and chlortetracycline hydrochloride (Kóňová et al. 1998, 1999). Morphology and morphometry of thyroid gland in farm animals in relation to their age and weight category, nutrition, saturation with iodine and exploitation were studied by Kratoch víl (1998). The author found that the largest follicles 
were in cattle weighing $450 \mathrm{~kg}$ and the smallest ones were in cows above $600 \mathrm{~kg} \mathrm{b.m}$. He observed the highest follicular epithelium in animals of body mass category of $501-550 \mathrm{~kg}$.

Immunohistochemical detection of PCNA is frequently used for the estimation of cellular proliferative activity, especially in oncological pathology (Lu káš et al. 1997). Using PCNA index, Velický et al. (1997) proved increased proliferation of follicular epithelium in experimental rats treated with bromide as a goitrogenic agent. Di Fulvio et al. (2000) used PCNA for evaluation of triiodthyronine on proliferative activity of bovine thyrocytes cultivated in vitro. It is well documented that AgNOR are in close relation to the proliferative activity of cells. In available literature only Serakides et al. (1999) used quantification of AgNOR for the estimation of the proliferative effect of methythiouracil on bovine thyroid gland. The authors, consider the AgNOR technique as efficient for the evaluation of the proliferative activity of follicular epithelium. We proved high positive correlation. between these two markers of proliferation though they areinvolved in different mechanisms of regulation of cellular division.

\section{Hodnocení aktivity thyreoidey pomocí morfometrie, PCNA a AgNOR}

Cílem této studie bylo přispět ke zvýšení objektivity morfologického vyšetření štítné žlázy skotu.Štítná žláza euthyreoidních krav je tvořena folikuly výrazně rozdílné velikosti. Pomocí analýzy obrazu byly folikuly na základě jejich průměru rozděleny do tří kategorií velké (175,1-615 $\mu \mathrm{m})$, střední $(80,1-175 \mu \mathrm{m})$ a malé $(15-80 \mu \mathrm{m})$. Zjistili jsme také výrazné individuální rozdíly $\mathrm{v}$ množství jednotlivých velikostních kategorií folikulů. Výška folikulárního epitelu byla $\mathrm{v}$ obráceném poměru $\mathrm{k}$ velikosti folikulů a průměrné hodnoty byly 7,06 $\mu \mathrm{m}, 8,04 \mu \mathrm{m}$ a 8,39 $\mu \mathrm{m}$. Proliferační aktivita folikulárního epitelu hodnocená pomocí proliferativního nukleárního antigenu (PCNA) a nukleolárních organizátorů růstu (AgNOR) byla vysoká v malých folikulech, střední ve středních folikulech a nízká ve velkých folikulech. Zjistili jsme, že oba tyto markery jsou vhodné pro hodnocení proliferační aktivity folikulárního epitelu v thyreoideách skotu.

\section{Acknowledgement}

This work was supported by MŠMT CEZ J06/98 122200002; NAZV EP 9269.

\section{References}

BANKS, WJ 1992: Applied Veterinary Histology. $3^{\text {rd }}$ Ed. Mosby-Year Book, Inc, St. Louis, 527 p.

COPENHAUER, WM 1964: Bailey's Textbook of Histology. $15^{\text {th }}$ Ed., The Wiliams and Wilkins Comp. Baltimore, $679 \mathrm{p}$.

COTRAN, RS, KUMAR, V, ROBBINS, SL 1994: Pathologic Basis of Disease. Saunders. Philadelphia, 1400 p.

DiFULVIO, M, COLEONI, AH, PELLIZAS, CG, MASINI-REPISO, AM 2000: Tri-iodothyronine Induces Proliferation in Culture Bovine Thyroid Cells: Evidence for the Involvement of Epidermal Growth Factorassociated Tyrosine Kinase Activity. J Endocrinol 166: 173-182

FITZGERALD, S 1983: Sheep Production. $1^{\text {st }}$ Ed. London, Butterworths, 239

HIKINO, T, FUKUSHIMA, T, SAITO, M, HARA, F, OYAMA, T, FUKUDA, T, NAKAJIMA, T 1995: A Simple Silver Stain for Fungi Using the Silver Colloid Solution for AgNOR Stain. Pathology International 45: 172-173

JUBB, KVF, KENNEDY, PC, PALMER, N 1993: Pathology of Domestic Animals. Vol. 3. Academic Press, San Diego, $653 \mathrm{p}$.

KÓŇOVÁ, M, BÉKEOVÁ, E, PAUER, T, LEVKUT, M 1998: Height of the epithelial cells and diameter of follicles of the thyreoidea in lambs after long-termed intake of high and low doses of chlorine (In Slovak). In: Symp. Imunocytoch. klin. vet. med., Univ. vet. lekár., Košice, pp. 45-49

KÓNOVÁ, M, BÉKEOVÁ, E, PAUER, T, LEVKUT, M 1999: The Effect of Chlortetracycline Hydrochloride on some Morphometric Parameters of the Thyroid Gland. Vet Med-Czech 44: 193-197

KRATOCHVÍL, P 1998: Morphological changes in the thyroid gland of farm animals under different breeding conditions. (In Czech). Dissertation. South Bohemian University, České Budějovice, Agricultural Faculty, 1998,193 p.

LUKÁŠ, Z, DRÁBEROVÁ, E, FEIT, J, VOJTĚŠEK B. 1997: Imunohistochemické metody v biologii a v bioptické diagnostice. Masarykova univerzita Brno, $147 \mathrm{p}$. 
MATOUŠKOVÁ, O, CHALUPA, J, CÍGLER, M, HRUŠKA, K 1992: Statistický a grafický systém Statplus verze 101. Brno, VÚVEL, $168 \mathrm{p}$.

McGAVIN, DM, CARLTON, WW, ZACHARY, JF 2001: Thomsons Special Veterinary Pathology. Mosby, St. Louis, $755 \mathrm{p}$.

NOVOTNÝ, E, BÖHM, R, GEISSEL, V, HOLMAN, J 1966: Veterinární histologie. Státní zemědělské nakladatelství Praha, $637 \mathrm{p}$.

SCHORSCH, F, POHLMEYER-ESCH, G 2001: Assessment of Follicular Cell Proliferation in the Rat Thyroid Gland: Proposal for double Immunostaining Procedure and Measure Strategy. Eur J Vet Pathol 7: 61-66

SERAKIDES, R, NUNES, VA, SANTOS, RL, CASSALI, GD, COSTA NETO, PP 1999: Histomorphometry and Quantification of Nucleolar Organizer Regions in Bovine Thyroid Containing Methylthiouracil Residues. Vet Pathol 36: 574-582

VELICKÝ J, TITLBACH M, LOJDA, Z, JELÍNEK, F, VOBECKÝ, M, RAŠKA, I 1997: Expression of the Proliferating Cell Nuclear Antigen (PCNA) in the Rat Thyroid Gland after Exposure to Bromide. Acta Histochem 99: 391-399 
Plate V

Jelínek F. et al.: Special Properties... pp. 11-16

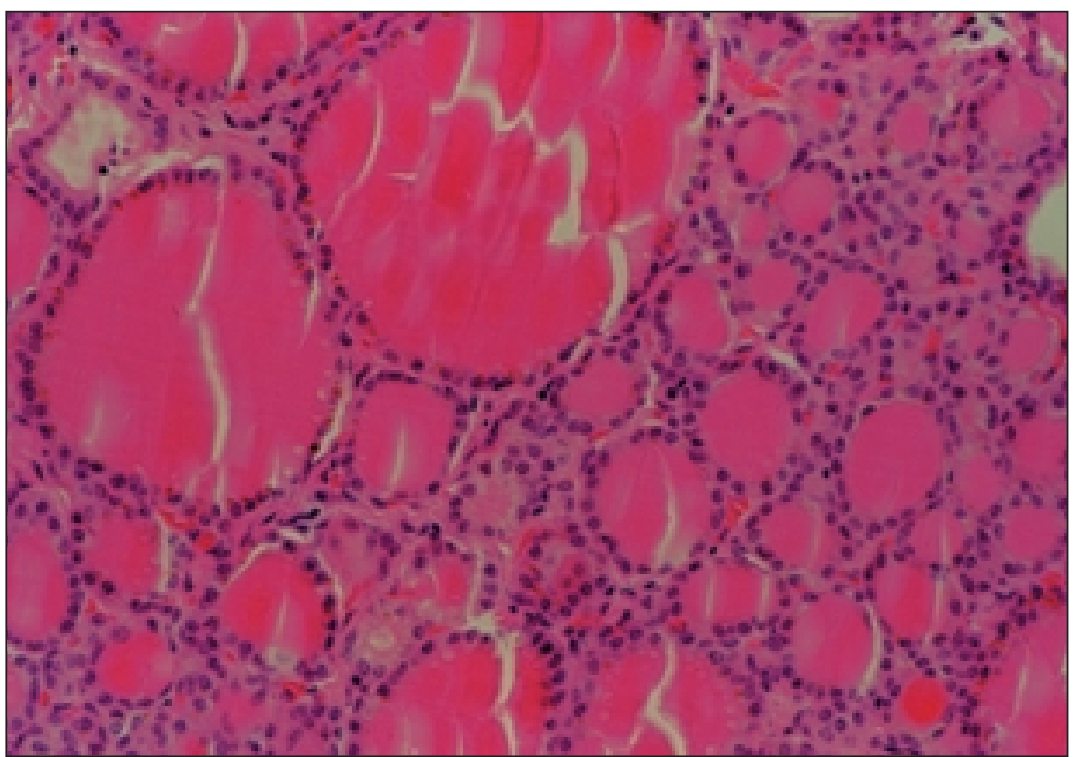

Fig. 1. Bovine thyroid gland. Prevalence of small follicles lined with low and tall cuboidal epithelium. In areas of small follicles there are solid nests of follicular cells. Mild, local increasing of the interfollicular connective tissue is apparent. Resorption vacuoles of the colloid are sporadic. Staining with HE, original magnification $\times 80$

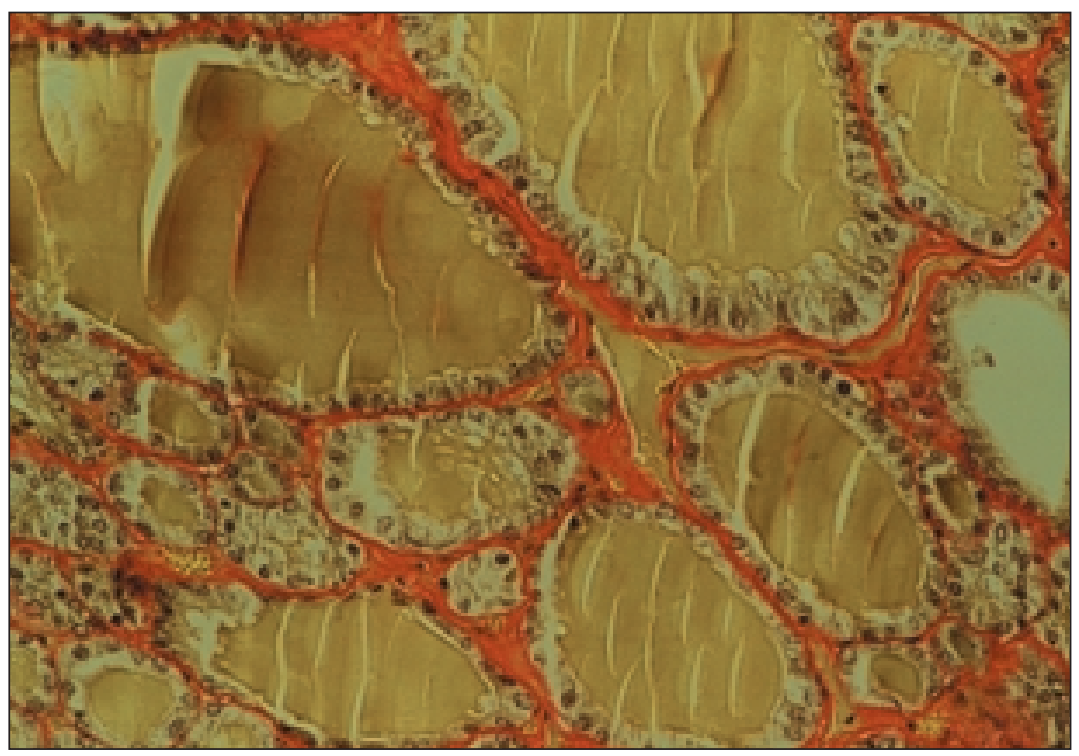

Fig. 2. Bovine thyroid gland. Medium and large follicles are lined with low and tall cuboidal epithelium. The cytoplasm of some cells is light-coloured. Sporadic resorption vacuoles of colloid are present. Microfollicles are predominantly lined with cuboidal or tall cuboidal epithelium and here and there are columnar epithelial cells with light vacuolated cytoplasm. Colloid is homogeneous with some resorption vacuoles. Staining after van Gieson, original magnification $\times 160$. 


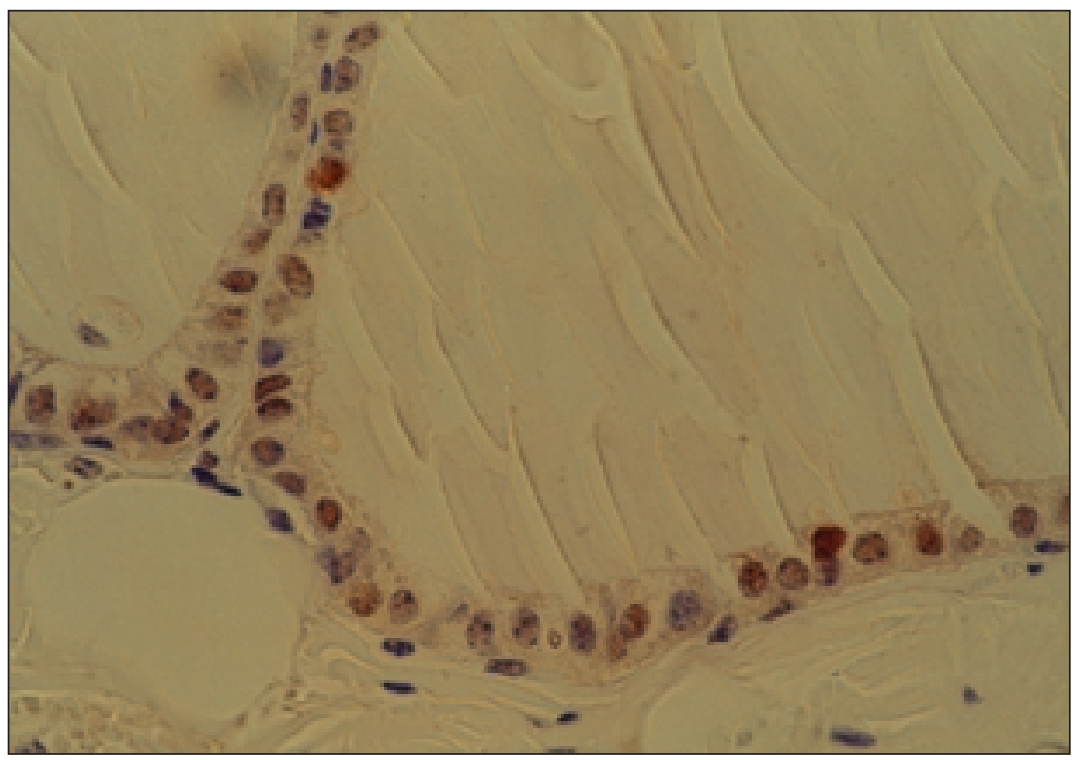

Fig. 3. Bovine thyroid gland. Nucleolar organizer regions (AgNOR) have a form of the dark-brown round corpuscles located in the nuclei. In majority of the cells there is more than one corpuscle. Staining after Hikino, original magnification $\times 320$.

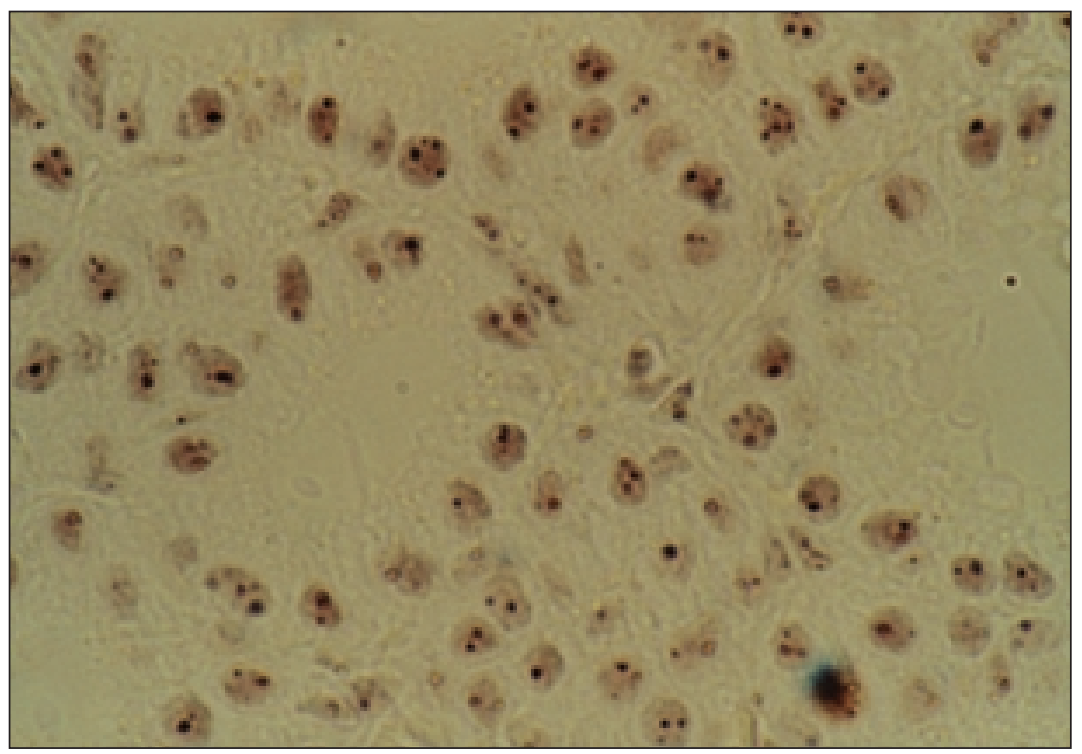

Fig. 4. Bovine thyroid gland, PCNA. Nuclei of the proliferating cells are brown coloured. Immunoperoxidase reaction, original magnification $\times 160$. 